\title{
PERLIDUNGAN JUSTICE COLLABORATOR TINDAK PIDANA KORUPSI
}

JUPRI

Fakultas Hukum Universitas Ichsan Gorontalo

Email: jupri04hukum@gmail.com

\begin{abstract}
ABSTRAK
Pemberian perlindungan terhadap seorang yang berstatus saksi pelaku yang bekerjasama (Justice Collaborator) diatur dalam Artikel 32 United Nation Convention Against Corruption, 2003) sebagaimana diratifikasi menjadi UndangUndang Nomor 7 Tahun 2006 menegaskan setiap negara peserta wajib untuk memberikan perlindungan secara fisik dan psikis terhadap saksi dan ahli dalam pengungkapan tindak pidana korupsi. Seiring perkembangan pengungkapan tindak pidana korupsi di Indonesia, pengaturan Justice Collaborator ini kemudian mulai diatur secara tegas dalam Undang-Undang Nomor 31 Tahun 2014 tentang Perlindungan Saksi dan Korban.

Walaupun jaminan perlindungan fisik, hukum dan penanganan secara khusus terhadap Justice Collaborator telah ada. Faktanya dalam dalam pengungkapan tindak pidana korupsi yang bersifat organized crime, seorang saksi pelaku yang bekerjasama dengan penegak hukum mendapatkan intimidasi sampai ancaman akan dibunuh. Misalnya dalam pengungkapan kasus korupsi yang melibatkan sejumlah politisi Partai Politik di Indonesia.
\end{abstract}

Kata Kunci: Justice Collaborator, Perlindungan, Tindak Pidana KorupsI

\section{ABSTRACT}

The guaranted of protection to a Justice Collaborator is stipulated in Article 32 of the United Nations Convention Against Corruption, 2003) as ratified as Law Number 7 Year 2006 stipulates that each State Party is obliged to provide physical and psychological protection against witnesses and experts in the disclosure of criminal acts of corruption. As the development progresses of corruption disclosure in Indonesia, the arrangement of Justice Collaborator is then started to be regulated explicitly in Law Number 31 Year 2014 on Protection of Witness and Victim.

Although physical, legal and special protection guarantees against the Justice Collaborator already exist. In fact, in the disclosure of a crime of corruption committed crime, a witness of the perpetrator who cooperates with law 
enforcement gets bullied until threats are killed. For example in the disclosure of corruption cases involving a number of politicians Political Parties in Indonesia.

Keywords: Justice Collaborator, Protection, Corruption

\section{PENDAHULUAN}

Transparency International setiap tahun merilis indeks persepsi korupsi negara-negara di dunia. Negara Indonesia di dua tahun terakhir masih berada pada urutan ke 88 dari 165 negara dalam peringkat indeks persepsi korupsi dan tahun 2016 skor CPI Indonesia menempati urutan 90 dari 176 negara. Artinya Indonesia masih tergolong negara yang darurat korupsi. Dampak dari meningkatnya tindak pidana korupsi yang tidak terkendali akan membawa bencana pada kehidupan berbangsa dan bernegara. Hancurnya perekonomian nasional akan semakin menjauhkan dari cita kesejahteraan bagi seluruh rakyat Indonesia.

Maraknya perilaku korupsi memiliki sejarah yang panjang di Indonesia. Pada masa-masa awal pemerintahan Presiden Soeharto, mantan Wakil Presiden Indonesia yang pertama, Muhammad Hatta ditunjuk menjadi penasihat Presiden dalam upaya pemberantasan korupsi. Dalam kapasitasnya sebagai seorang penasihat Presiden, Hatta pernah mengungkapkan bahwa "Korupsi telah membudaya di Indonesia. Artinya perilaku menggarong uang negara telah massif dipraktikkan para pejabat publik. Perilaku koruptif telah merasuki sendisendi kehidupan berbangsa dan bernegara. Di saat yang sama seluruh rakyat Indonesia permisif akan hal tersebut.

Bila kita melihat dari segi pelaku tindak pidana korupsi berdasarkan Jabatan, Komisi Pemberantasan Korupsi mencatat dari tahun 2004 sampai per 31 Maret 2014. Pelaku korupsi terdiri dari Anggota DPR dan DPRD berjumlah 73 orang, Kepala Lembaga/ Kementerian berjumlah 12 orang, Duta Besar berjumlah 4 orang, Komisioner berjumlah 7 orang, Gubernur berjumlah 10 
orang, Walikota/ Bupati dan Wakil berjumlah 35 orang, Eselon I/ II/ III berjumlah 115, Hakim berjumlah 10 orang, Swasta berjumlah 95 orang dan lainnya berjumlah 41 orang. Total pelaku korupsi yang dijebloskan KPK yakni 402 orang. Termasuk di dalamnya 2 (dua) pimpinan Partai Politik dan 3 (tiga) Menteri di masa Pemerintahan SBY-Boediono.

Data di atas semakin mengkonfirmasi ciri negara Indonesia sudah tergolong kleptokrasi. Suatu negara yang dikuasai para maling. Nampak seluruh cabang kekuasaan baik eksekutif, yudikatif dan legislatif tidak lupuk dari cengkraman korupsi. Berujung pada kesimpulan mengorupsi trias politica meminjam istilah Laode M. Syarif.

Padahal pada era reformasi keseriusan pemerintah dalam memberantas korupsi ditandai dengan lahirnya Undang-Undang Nomor 28 Tahun 1999 tentang Penyelenggara Negara Yang Bersih dan Bebas Korupsi, Kolusi dan Nepotisme, Undang-Undang Nomor 31 Tahun 1999 sebagaimana diubah dengan Undang-Undang Nomor 20 tahun 2001 tentang Pemberantasan Tindak Pidana Korupsi, Undang-Undang Nomor 30 Tahun 2002 tentang Komisi Pemberantasan Korupsi, dan Undang-Undang Nomor 46 Tahun 2009 tentang Pengadilan Tindak Pidana Korupsi, serta disahkannya United Nations Convention Againts Corruption 2003 menjadi Undang-Undang Nomor 7 Tahun 2006.

Ciri negara kleptokrasi menguatkan posisi para pelaku korupsi dengan kekuasaan besar untuk membentengi diri dari penegak hukum. Relasi kuasa yang besar dan materi berlimpah menyulitkan penegak hukum untuk mengungkap keterlibatan pihak-pihak dalam kejahatan yang tergolong organized crime ini. Olehnya dibutuhkan strategi pengungkapan tindak pidana korupsi lewat peran substansial seorang Whistleblowers dan Justice Collaborator.

Istilah Whistleblowers merupakan istilah baru dalam Hukum Acara Pidana di Indonesia. Namun, di Indonesia terdapat istilah "saksi mahkota" atau 
crown witness, yakni salah satu pelaku tindak pidana ditarik sebagai saksi kunci untuk mengungkap pelaku-pelaku yang lain dengan iming-iming pengurangan ancaman hukuman. Sistem ini sudah lama diterapkan di negara Eropa Kontinental seperti Belanda, Prancis, dan Italia dengan menggunakan konsep Protection of Cooperating Person, sedangkan Konsep Whistleblowers lebih banyak diusung oleh negara-negara Anglo Saxon, khususnya Amerika dan negara-negara common whealth (negara-negara persemakmuran, bekas jajahan Inggris). Sekalipun demikian konsep Whistleblowers dan konsep Protection of Cooperating Person merupakan dua hal yang sangat berbeda. si pengungkap fakta pada konsep Whistleblowers sama sekali tidak dipidana, sedangkan si pengungkap fakta pada konsep Protection of Cooperating Person tetap bisa dipidana namun mendapatkan keringanan. Konsep Protection of Cooperating Person lebih terkonsentrasi kepada pelaku yang bekerjasama dengan penegak hukum (Justice Collaborator) dalam mengungkap kerumitan kasus 39

Sedangkan menurut Romli Atmasasmita, membedakan antara Whistleblower dengan Justice Collaborator. Whistleblower adalah setiap orang lazimnya korban yang kemudian bersaksi memberikan keterangan kepada penyidik mengenai seluk beluk tindak pidana yang ia ketahui dan dengar sendiri bahkan ia alami sendiri. Dengan itu dia mendapatkan jaminan perlindungan atas keamanan (fisik) dibawah supervisi kepolisian. Caranya dengan mengubah identitas, menempatkan di suatu lokasi tertentu dan berada di bawah pengawasan superketat dari pihak intelijen kepolisian. Tujuan dari keberadaan Whistleblower adalah memudahkan tugas penyidik sehingga suatu perkara dapat diungkap tuntas sampai kepada intellectual-dader dan pimpinan organisasi kejahatan. Sementara Justice Collaborator adalah setiap tersangka yang terlibat organisasi kejahatan dan telah melakukan suatu tindak pidana baik atas inisiatif sendiri maupun atas permintaan aparatur hukum untuk

${ }^{39}$ Firman Wijaya, Whistle Blower dan Justice Collaborator Dalam Perspektif Hukum, Penaku, Jakarta, 2012, Hlm. 11-12 
bekerjasama dengan penegak hukum menemukan alat-alat bukti dan barang bukti sehingga penyidikan dan penuntutan dapat berjalan efektif. Perlindungan terhadap Whistleblower berbeda dengan Justice Collaborator. Perlindungan hukum terhadap Whistleblower sebatas perlindungan fisik sedangkan perlindungan terhadap Justice Collaborator tidak sebatas fisik melainkan juga "keringanan-keringanan yang bisa ditawarkan ${ }^{40}$

Kemudian istilah Justice Collaborator juga sama dengan saksi pelaku sebagaimana diatur dalam Undang-Undang Nomor 13 Tahun 2006 jo UndangUndang Nomor 31 Tahun 2014 tentang Perlindungan Saksi dan Korban. Pasal 1 ayat (2) menegaskan saksi pelaku adalah tersangka, terdakwa, atau terpidana yang bekerjasama dengan penegak hukum untuk mengungkap suatu tindak pidana dalam kasus yang sama.

Pada konteks pengungkapan inilah keberadaan seorang Justice Collaborator menjadi hal yang sangat penting dalam rangka membongkar jaringan kejahatan yang selama ini tertutup rapi dan sangat terorganisir. Justice collaborator merupakan salah satu upaya yang dilakukan untuk membongkar suatu kejahatan yang terorganisir, seperti jaringan mafia, termasuk korupsi yang biasanya dilakukan secara berjamaah. Kategori extraordinary crime jelas membutuhkan extra ordinary measures, sebab perlindungan hukum sangat diperlukan bagi Justice Collaborator terhadap kegiatannya yang melawan hukum $^{41}$

Salah satu contoh peran substansial Justice Collaborator dalam mengungkap tindak pidana korupsi tergambar dalam pengungkapan kasus suap wisma atlet. Seorang berstatus JC atau saksi pelaku yang bekerjasama dengan penegak hukum dari Komisi Pemberantasan Korupsi membongkar keterlibatan

\footnotetext{
${ }^{40} \mathrm{http}: / /$ budisansblog.blogspot.com/2012/05/justice-collaborator-mungkinkah.html.

${ }^{41}$ Abdul Haris, Optimalisasi Perlakuan dan Perlindungan Bagi Whistleblower dan Justice Collaborator. Makalah disampaikan dalam kegiatan Kuliah Umum Fakultas Hukum Universitas Hasanuddin, Makassar 20 Oktober 2014
} 
Bendahara Umum Partai Demokrat M. Nazaruddin, Mohamad El Idris, Sesmenpora Wafid Muharram, Yulianis, dan Angelina Sondakh. Pengembangan kasus ini juga membongkar indikasi kasus korupsi Hambalang dan Kemendiknas. Sejumlah nama politisi muda top tanah air terjerat, sebut saja Menpora Andi Alfian Mallarangeng dan Ketua Umum Partai Demokrat Anas Urbaningrum.

Atas jasa kolaborasi yang diberikan Justice Collaborator, serta keberanian dalam mengungkap keterlibatan pihak-pihak dalam kasus korupsi yang dibongkarnya. Maka penegak hukum wajib kiranya memberikan perlindungan super ketat kepada seorang Justice Collaborator, karena sangat rentan menjadi korban aksi balas dendam. Oleh karena itu, sudah tepat kiranya pemerintah lewat Undang-Undang Perlindungan Saksi dan Korban memberikan hak-hak bagi Justice Collaborator berupa perlindungan baik fisik, perlindungan hukum dan penanganan secara khusus. Sebagai wujud dari diratifikasinya United Nations Convention Againts Corruption, 2003 Pasal 32 menegaskan setiap negara peseta wajib mengambil tindakan-tindakan yang tepat sesuai dengan sistem hukum yang berlaku di negaranya, dan dengan segala cara menyediakan perlindungan yang efektif dari kemungkinan pembalasan atau ancaman/ intimidasi terhadap para saksi dan saksi ahli yang memberikan kesaksian mengenai tindak pidana yang ditetapkan sesuai dengan konvensi ini, serta sejauh diperlukan bagi keluarga mereka dan orang-orang lain yang dekat dengan mereka.

Ironis walaupun pemerintah sudah mengatur secara tegas dalam sejumlah peraturan perundang-undangan mengenai perlindungan bagi seorang Justice Collaborator. Realitasnya seorang Justice Collaborator masih memperoleh ancaman dari pihak-pihak yang takut keterlibatannya dalam kasus korupsi terungkap. 


\section{RUMUSAN MASALAH}

1. Bagaimana pemberian perlidungan fisik terhadap Justice Collaborator perkara korupsi?

2. Bagaimana pemberian perlindungan hukum terhadap Justice Collaborator perkara korupsi?

3. Bagaimana pemberian penanganan secara khusus terhadap Justice Collaborator perkara korupsi?

\section{METODE PENELITIAN}

Penelitian ini dilakukan dengan metode penelitian empiris (empirical research). Tipe penelitian empiris dipilih untuk menganalisis dan menjawab pertanyaan sejauhmana pemberian perlindungan fisik, perlindungan hukum dan penanganan secara khusus bagi seorang pelaku yang berstatus Justice Collaborator untuk perkara tindak pidana korupsi.

Jenis data yang akan digunakan dalam proses pelaksanaan penelitian, yaitu (a) data primer, berupa data yang berasal dari data lapangan. Data lapangan itu diperoleh dari para responden dan informan terkait apa yang diteliti. (b) data sekunder, yaitu data yang diperoleh dari kajian atau penelaahan berbagai sumber kepustakaan dokumen, peraturan perundang-undangan, laporan-laporan, dan putusan pengadilan yang berkaitan dengan Justice Collaborator perkara korupsi.

Adapun teknik pengumpulan data yang digunakan adalah (a) metode wawancara, yakni pengumpulan data secara langsung kepada informan dalam bentuk tanya jawab yang berkaitan dengan bagaimana pemberian perlindungan fisik, perlindungan hukum dan penanganan secara khusus bagi Justice Collaborator dalam mengungkap tindak pidana korupsi yang tergolong organized crime. (b) studi dokumentasi, yakni pengumpulan data melalui pencatatan informasi dan dokumentasi yang telah ada dan berkaitan dengan 
permasalahan penelitian, dan dokumen tersebut bersifat sebagai bahan kajian yang relevan dengan penelitian. Kemudian seluruh data yang diperoleh dalam penelitian ini baik data primer maupun data sekunder dianalisis dengan menggunakan teknik analisis kualitatif. Dengan tujuan untuk mendeskripsikan bagaimana penegak hukum dan pihak terkait dalam hal pemberian perlindungan baik fisik, perlindungan hukum, dan penanganan secara khusus bagi seorang Justice Collaborator dalam mengungkap pihak-pihak yang terkait dalam tindak pidana korupsi.

\section{PEMBAHASAN}

\section{Pemberian Perlindungan Fisik Terhadap Justice Collaborator}

Komisi Pemberantasan Korupsi sebagai lembaga negara yang dibentuk berdasarkan Undang-Undang Nomor 30 Tahun 2002 Tentang Komisi Pemberantasan Tindak Pidana Korupsi yang berdasarkan Pasal 15 huruf (a) menegaskan bahwa KPK berkewajiban memberikan perlindungan terhadap saksi atau pelapor yang menyampaikan laporan atau memberikan keterangan mengenai terjadinya tindak pidana korupsi.

Indriyanto Seno Adji (2009:449) menegaskan dari pendekatan historis, perlindungan hukum terhadap saksi dan pelapor adalah imperatif sifatnya, bahkan norma reward menjadi sandaran legislasi yang patut dihargai. Namun demikian, perlindungan hukum tidak memiliki eksepsionalitas yang absolut dan tidak berlaku terhadap terhadap saksi atau pelapor yang terlibat delik korupsi. Karena itu prinsip Lex Certa adalah norma mengikat yang tidak dapat diintrepetasikan lain dari maksud yang diaturnya substansi norma tersebut. Pasal 31 UU Nomor 31 Tahun 1999 maupun Penjelasannya tidak memberikan perlindungan hukum terhadap saksi dan pelapor yang terlibat delik korupsi. KPK, sesuai Pasal 15 UU Nomor 30 Tahun 2002 maupun Penjelasannya, wajib memberikan perlindungan Saksi dan Pelapor mengenai terjadinya tindak pidana korupsi. Namun, demikian, asas perlindungan ini bersifat Physically Protection 
(keamanan, evakuasi atau perubahan identitas), selain itu tentunya perlindungan hanya berlaku terhadap non criminal person protection, artinya tidak berlaku terhadap saksi atau pelapor yang memang terlibat dugaan korupsi.

Sejalan dengan itu, perlindungan terhadap Justice Collaborator oleh Rini Afriyanti $^{42}$ (Biro Hukum KPK) mengemukakan bahwa Biro Hukum Komisi Pemberantasan Korupsi memiliki program perlindungan terhadap saksi. Hanya saja, KPK wajib memberikan perlindungan terhadap saksi fakta saja bukan saksi pelaku. Untuk saksi pelaku atau Justice Collaborator setelah ditetapkan statatusnya oleh Komisi Pemberantasan Korupsi, langsung diserahkan ke Lembaga Perlidungan Saksi dan Korban, demi mencegah terjadinya konflik kepentingan. Adapun peran KPK dalam konteks ini tetap menjalin koordinasi dengan LPSK.

LPSK yang lahir berdasarkan Undang-Undang Nomor 13 Tahun 2006 jo Undang-Undang Nomor 31 Tahun 2014 Tentang Perlindungan Saksi dan Korban menegaskan hak-hak bagi saksi pelaku:

a. Memperoleh perlindungan atas keamanan pribadi, keluarga dan harta bendanya serta bebas dari ancaman yang berkenaan dengan kesaksian yang akan, sedang atau telah diberikannya.

b. Ikut serta dalam proses memilih dan menentukan bentuk perlindungan dan dukungan keamanan.

c. Memberikan keterangan tanpa tekanan.

d. Mendapat penerjemah.

e. Bebas dari pertanyaan menjerat.

f. Mendapatkan informasi mengenai perkembangan kasus.

g. Mendapatkan informasi mengenai putusan pengadilan.

h. Mengetahui dalam hal terpidana dibebaskan.

i. Dirahasiakan identitasnya.

j. Mendapat identitas baru.

\footnotetext{
${ }^{42}$ Wawancara Tanggal 24 Juni 2015.
} 
k. Mendapatkan tempat kediaman sementara.

l. Mendapat tempat kediaman baru.

m. Memperoleh penggantian biaya transportasi sesuai dengan kebutuhan.

n. Mendapat nasihat hukum;

o. Memperoleh bantuan biaya hidup sementara sampai batas waktu perlindungan berakhir.

p. Mendapat pendampingan.

q. Tidak dapat dituntut secara hukum, baik pidana maupun perdata atas kesaksian dan/ atau laporan yang akan, sedang atau telah diberikannya, kecuali kesaksian atau laporan tersebut diberikan tidak dengan iktikad baik.

r. Dalam hal terdapat tuntutan hukum atas kesaksian dan/ atau laporan yang akan, sedang atau telah diberikan, tuntutan hukum tersebut wajib ditunda hingga kasus yang ia laporkan atau ia berikan kesaksian telah diputus oleh pengadilan dan memperoleh kekuatan hukum tetap.

Hak-hak tersebut di atas, lagi dapat dikelompokkan ke dalam layanan perlindungan dan layanan dukungan hak prosedural. Dalam kaitannya dengan pemenuhan hak justice collaborator oleh Lili Pintauli ${ }^{43}$ (Wakil Ketua LPSK Penanggung Jawab Divisi Pemenuhan Hak-Hak Saksi dan Korban) mengemukakan:

“Pengelompokan layanan perlidungan dan layanan hak prosedural memang tidak dikenal dalam Undang-Undang Nomor 13 Tahun 2006 jo Undang-Undang Nomor 31 Tahun 2014 Tentang Perlindungan Saksi dan Korban. Pembagian tersebut dianut dari konsep perlindungan hukum saksi di Amerika Serikat oleh US. Marshals."

\footnotetext{
${ }^{43}$ Wawancara tanggal 25 Juni 2015.
} 
Peran LPSK dalam mengelompok-kan hak-hak saksi dan korban, sebagai rangkaian lebih lanjut pelayanan hak prosedural terdiri atas: memberikan keterangan tanpa tekanan, mendapat penerjemah, bebas dari pertanyaan yang menjerat, mendapat informasi mengenai perkembangan kasus, mendapat informasi mengenai putusan pengadilan, mendapat informasi dalam hal terpidana dibebaskan, memperoleh penggantian biaya transportasi sesuai dengan kebutuhan, dan mendapat nasihat hukum.

Dalam praktik sebagaimana penelitian yang telah dilakukan, data yang diperoleh sebagai permohonan Justice Collaborator untuk mendapatkan perlindungan ke LPSK pada tahun 2012 sebanyak 8 (delapan) orang sedangkan pada tahun 2014 terdapat 14 (empat belas) orang yang kesemuanya telah mendapatkan layanan perlindungan. Sebagaimana Rini Afriyanti ${ }^{44}$ (Biro Hukum KPK) mengemukakan bahwa seluruh tersangka korupsi yang berstatus Justice Collaborator yang dimohonkan ke LPSK semuanya diterima.

Penetapan Justice Collaborator pada hakikatnya harus mengikuti standar yang telah ditentukan dalam undang-undang. Hal ini ditegaskan dalam Pasal 28 ayat (2) Undang-Undang Nomor 31 Tahun 2014: "perlindungan LPSK terhadap Saksi Pelaku diberikan atas dasar pertimbangan sebagai berikut:

a. Tindak pidana yang akan diungkap merupakan tindak pidana dalam kasus tertentu sesuai dengan keputusan LPSK sebagaimana dimaksud dalam Pasal 5 ayat (2).

b. Sifat pentingnya keterangan yang diberikan oleh Saksi Pelaku dalam mengungkap suatu tindak pidana.

c. Bukan sebagai pelaku utama dalam tindak pidana yang diungkapkannya

d. Kesediaan mengembalikan asset yang diperoleh dari tindak pidana yang dilakukan dan dinyatakan dalam pernyataan tertulis, dan

\footnotetext{
${ }^{44}$ Wawancara tanggal 24 Juni 2015
} 
e. Adanya ancaman yang nyata atau kekhawatiran akan terjadinya ancaman, tekanan secara fisik atau psikis terhadap Saksi Pelaku atau Keluarganya jika tindak pidana tersebut diungkap menurut keadaan yang sebenarnya.

Dengan demikian Komisi Pemberantasan Korupsi tidak dengan serta merta akan mengabulkan permohonan atau meminta seseorang menjadi Justice Collaborator. Prof. Teguh Soedarsono 45 (Wakil Ketua LPSK) mengemukakan:

"Bahwa pemberian status Justice Collaborator oleh penegak hukum tidak boleh mudah diberikan, karena ketika sudah ditetapkan maka secara otomatis berhak mendapatkan hak-hak, perlakuan secara khusus dan reward sebagaimana diatur dalam peraturan perundang-undangan. Hanya saja di sejumlah daerah, kejaksaan pun sudah sering menetapkan seseorang menjadi Justice Collaborator perkara korupsi, sebagai kasus di Tangerang Selatan yang pernah ditangani oleh LPSK, ada seorang jaksa meminta uang sebesar Rp. 100 juta untuk menjadikan pelaku sebagai Justice Collaborator. Padahal berdasarkan pengamatan kami, pelaku sudah memberikan informasi dan kerjasamanya dalam membongkar kasus korupsi. Pernah juga seseorang telah diberikan status Justice Collaborator, dia pun memperoleh hak-haknya tetapi di muka sidang tidak terlalu bekerjasama."

Walaupun LPSK berkewajiban memberikan perlindungan kepada Justice Collaborator, faktanya tidak semuanya di lindungi. Karena ternyata sebagaimana pengakuan Lili Pintauli ${ }^{46}$ :

"Bahwa memang sejatinya Justice Collaborator harus mendapatkan perlindungan secara fisik, tetapi pernah juga seorang Justice Collaborator kasus suap cek pelawat pemilihan Gubernur Senior Bank Indonesia justru

\footnotetext{
${ }^{45}$ Wawancara 29 Juni 2015

${ }^{46}$ Wawancara tanggal 25 Juni 2015
} 
menolak memperoleh perlindungan dengan alasan dirinya tidak mengalami ancaman."

Hal yang berbeda dengan penetapan MRM sebagai Justice Collaborator, ternyata kasus yang akan diungkap olehnya memang tersebar dibeberapa kementerian dan melibatkan sejumlah politisi dan pejabat negara. Dia mengaku mendapatkan ancaman, sehingga LPSK memberikan pengawalan ekstra. Artinya, kemanapun MRM maka harus selalu di dampingi. Selain itu, MRM sebenarnya ketika akan memberikan kesaksian awalnya sangat takut karena diancaman akan dibunuh. Pihak LPSK meminta kepada hakim agar pemberian kesaksian menggunakan alat video teleconference, tetapi ditolak dengan alasan lebih baik bertemu langsung dengan terdakwa Nazaruddin karena selama ini Nazaruddin mengaku tidak mengenal MRM. Akhirnya untuk menghadirkan saksi yang sudah beberapa kali tertunda pemeriksaannya, MRM diberikan rompi anti peluru sebagai pengamanan dan alternatif tetap di sediakan video teleconference oleh pihak Komisi Pemberantasan Korupsi.

\section{Pemberian Perlindungan Hukum Terhadap Justice Collaborator}

Seorang saksi pelaku dalam memberikan informasi kepada penegak hukum terkait tindak pidana yang akan diungkap tidak jarang mengalami laporan balik dari pihak-pihak yang disebutnya. Atas dasar tersebut, pemerintah memberikan perlindungan hukum baik bagi saksi pelaku (Justice Collaborator) maupun saksi pelapor (Whistleblower).

Perlindungan hukum terhadap Saksi Pelapor pada mulanya diatur sebelum diterbitkan Undang-Undang Nomor 13 Tahun 2006 jo Undang-Undang Nomor 31 Tahun 2014 tentang Perlindungan Saksi dan Korban yakni termaktub dalam penjelasan Pasal 15 huruf (a) selanjutnya menyatakan bahwa yang dimaksud dengan "memberikan perlindungan", dalam ketentuan ini melingkupi juga pemberian jaminan keamanan dengan meminta bantuan kepolisian atau 
penggantian identitas pelapor atau melakukan evakuasi termasuk perlindungan hukum.

Sedangkan Pasal 41 ayat (2) huruf e Undang-Undang Nomor 31 Tahun 1999 menegaskan hak untuk memperoleh perlindungan hukum dalam hal melaksanakan (a) hak mencari, memperoleh, dan memberikan informasi adanya dugaan tindak pidana korupsi, (b) hak untuk memperoleh pelayanan dalam mencari, memperoleh, dan memberikan informasi adanya dugaan telah terjadi tindak pidana korupsi kepada penegak hukum yang menangani perkara tindak pidana korupsi, (c) hak menyampaikan saran dan pendapat seara bertanggungjawab kepada penegak hukum yang menangani perkara tindak pidana korupsi. Serta dimintai hadir dalam proses penyelidikan, penyidikan, dan disidang pengadilan sebagai saksi pelapor, saksi atau saksi ahli, sesuai dengan ketentuan peraturan perundang-undangan yang berlaku.

Kemudian hak masyarakat memperoleh perlindungan hukum guna melaksanakan peran sertanya lebih jauh diatur dalam Peraturan Pemerintah Nomor 71 Tahun 2000 Tentang Tata Cara Pelaksanaan Peran Serta Masyarakat dan Pemberian Penghargaan Dalam Pencegahan dan Pemerantasan Tindak Pidana Korupsi. Bab Ketiga Hak dan Tanggungjawab Masyarakat Dalam Memperoleh Perlindungan Hukum.

Khusus pemberian perlindungan hukum bagi saksi pelaku Uustice Collaborator) diatur dalam Peraturan Bersama Nomor: m.hh11.hm.03.02.th.2011, Nomor : per-045/a/ja/12/2011, Nomor: 1 tahun 2011, Nomor kepb-02/01-55/12/2011, Nomor: 4 tahun 2011 tentang Perlindungan Bagi Pelapor, Saksi Pelapor dan Saksi Pelaku yang Bekerjasama. Dimana Saksi pelaku yang bekerjasama berhak mendapatkan(a) perlindungan fisik dan psikis, (b) perlindungan hukum, (c) penanganan secara khusus dan (d) penghargaan.

Setelah revisi Undang-Undang Perlidungan Saksi dan Korban menjadi Undang-Undang Nomor 31 Tahun 2014, Perlindungan hukum bagi Justice Collaborator akhirnya diatur dalam Pasal 10, yang menegaskan bahwa: 
(1) Saksi, Korban, Saksi Pelaku, dan/atau Pelapor tidak dapat dituntut secara hukum, baik pidana maupun perdata atas kesaksian dan/atau laporan yang akan, sedang, atau telah diberikan, kecuali kesaksian atau laporan tersebut diberikan tidak dengan iktikad baik.

(2) Dalam hal terdapat tuntutan hukum terhadap Saksi, Korban, Saksi Pelaku, dan/atau Pelapor atas kesaksian dan/atau laporan yang akan, sedang, atau telah diberikan, tuntutan hukum tersebut wajib ditunda hingga kasus yang ia laporkan atau ia berikan kesaksian telah diputus oleh pengadilan dan memperoleh kekuatan hukum tetap.

Arti dari Pasal 10 di atas, dapat simpulkan seorang saksi pelaku Uustice Collaborator) selama kesaksian yang akan, sedang, atau telah diberikan didasari atas iktikad baik, maka ia tidak dapat dituntut baik pidana maupun perdata. Frasa "itikad baik" mensyaratkan agar seorang yang memberikan laporan dan/ atau kesaksian ke penegak hukum memang semata-mata didasarkan pada keinginan mengungkap kejahatan.

Namun, jikalau terdapat tuntutan hukum penegak hukum wajib menunda hingga kasus yang ia berikan kesaksian telah memperoleh kekuatan hukum tetap. Mengapa demikian? Pertama, agar supaya Justice Collaborator bisa tetap fokus memberikan kesaksian guna mengungkap fakta terjadinya tindak pidana. Kedua, langkah pencegahan (preventif) jangan sampai tuntutan hukum tersebut adalah upaya pihak tertentu untuk menghalang-halangi proses pemeriksaan perkara yang akan diungkap.

Dari penelitian yang telah dilakukan, dari semua perkara korupsi yang ditangani Komisi Pemberantasan Korupsi yang pengungkapannya melibatkan seorang berstatus Justice Collaborator tidak pernah mengalami "serangan balik" baik berupa laporan pencemaran nama baik maupun perbuatan tidak menyenangkan. 


\section{Pemberian Penanganan Secara Khusus Terhadap Justice Collaborator}

Penangan secara khusus sebelum revisi Undang-Undang Perlindungan Saksi dan Korban merupakan hak saksi pelaku yang bekerjasama sebagaimana diatur dalam Peraturan Bersama Menteri Hukum dan HAM, Jaksa Agung, Kepala Kepolisian Republik Indonesia, Komisi Pemberantasan Korupsi dan Ketua lembaga Perlindungan Saksi dan KorbanNomor: m.hh-11.hm.03.02.th.2011, Nomor : per-045/a/ja/12/2011, Nomor: 1 tahun 2011, Nomor kepb-02/0155/12/2011, Nomor: 4 tahun 2011. Adapun wujud penangan secara khusus bagi Justice Collaborator diantaranya:

a. Pemisahan tempat penahanan, kurungan atau penjara dari tersangka, terdakwa, dan/ atau narapidana lain dari kejahatan yang diungkap dalam hal Saksi pelaku yang Bekerjasama ditahan atau menjalani pidana badan.

b. Penundaan penuntutan atas dirinya

c. Penundaan proses hukum (penyidikan dan penuntutan) yang mungkin timbul karena informasi, laporan dan/ atau kesaksian yang diberikannya, dan/ atau

d. Memberikan kesaksian di depan persidangan tanpa menunjukkan wajahnya atau tanpa menunjukkan identitasnya.

Kemudian setelah terjadi revisi Undang-Undang Perlidungan Saksi dan Korban menjadi UU Nomor 31 Tahun 2014, maka penanganan secara khusus di atur dalam Pasal 10A yang menegaskan:

(1) Saksi Pelaku dapat diberikan penanganan secara khusus dalam proses pemeriksaan penghargaan atas kesaksian yang diberikan.

(2) Penangan secara khusus sebagaimana dimaksud pada ayat (1) berupa:

a. Pemisahan tempat penahanan atau tempat menjalani pidana antara Saksi Pelaku dengan tersangka, terdakwa, dan/ atau narapidana yang diungkap tindak pidananya. 
b. Pemisahan pemberkasan antara berkas Saksi Pelaku dengan berkas tersangka dan terdakwa dalam proses penyidikan, dan penuntutan atas tindak pidana yang diungkapnya, dan/ atau

c. Memberikan kesaksian di depan persidangan tanpa berhadapan langsung dengan terdakwa yang diungkap tindak pidananya.

Dalam praktiknya, pemenuhan hak-hak Justice Collaborator perkara korupsi dalam sistem peradilan pidana melalui penanganan secara khusus terlebih dahulu dilakukan pemisahan pemberkasan sebagaimana dikemukakan oleh Muhammad Asri Irawan ${ }^{47}$ (Jaksa KPK):

"Bahwa pada praktiknya pemisahan pemberkasan antara Justice Collaborator dengan pelaku lainnya dilakukan dengan cara split. Hal ini bertujuan agar pada pemeriksaan saat penyidikan tersangka bisa lebih leluasa atau merdeka memberikan keterangan tentang peran tersangkatersangka lain. Serta pada tahap pemeriksaan di persidangan mempermudah dalam hal pembuktian perkara".

Bentuk penanganan secara khusus ini terjadi dalam kasus AC selaku Justice Collaborator, AC mendapatkan penanganan secara khusus berupa (Lilik Mulyadi, 2015: 131-132):

a. Diberikan untuk memilih tempat dilaksanakannya pidana yaitu mendekatkan bersangkutan kepada keluarganya, dengan cara pemidahan dari Rutan Polda Metro Jaya ke Lembaga Pemasyarakatan Alas Roban, Jawa Tengah.

b. Diberikan ruang khusus kepada yang bersangkutan selama menjalani pidana. Pemberian ruang khusus ini juga sebagai bentuk pemberian perlindungan kepada yang bersangkutan terhadap kemungkinan adanya ancaman atau tindakan yang membahayakan keselamatan yang bersangkutan.

\footnotetext{
${ }^{47}$ Wawancara 22 Agusutus 2015.
} 
Selain AC, perlakuan secara khusus bagi Justice Collaborator dalam penindakan tindak pidana korupsi juga diperoleh oleh MRM. Saat MRM telah divonis 2 tahun 5 bulan penjara oleh Hakim Pengadilan Tipikor Jakarta, Ia kemudian menjalani pidana di Rumah Tahanan Komisi Pemberantasan Korupsi, karena sering menerima ancaman waktu menjadi penghuni Rutan Pondok Bambu.

Dalam memberikan perlakuan secara khusus bagi Justice Collaborator ternyata dilakukan koordinasi oleh beberapa lembaga. Sebagaimana Prof. Teguh Soedarsono 48 (Wakil Ketua LPSK) mengemukakan:

"Bahwa demi memberikan penanganan secara khusus kepada Justice Collaborator, maka LPSK melakukan kerjasama-kerjasama dengan instansi yang terkait dalam hal ini Kementerian Hukum dan HAM. Kerjasama tersebut dipertegas dalam Pasal 36 Undang-Undang Nomor 13 Tahun 2006 tentang Perlidungan Saksi dan Korban bahwa dalam melaksanakan pemberian perlindungan dan bantuan, LPSK dapat bekerja sama dengan instansi terkait yang berwenang".

\section{PENUTUP}

Berdasarkan peraturan perundang-undangan pemberian perlindungan terhadap seorang yang berstatus saksi pelaku yang bekerjasama Uustice Collaborator) diatur dalam Pasal 32 Konvensi Perserikatan Bangsa-Bangsa Anti Korupsi, 2003 (United Nation Convention Against Corruption, 2003) sebagaimana diratifikasi menjadi Undang-Undang Nomor 7 Tahun 2006 menegaskan setiap negara peserta wajib untuk memberikan perlindungan secara fisik dan psikis terhadap saksi dan ahli dalam pengungkapan tindak pidana korupsi. Seiring perkembangan pengungkapan tindak pidana korupsi di Indonesia, UNCAC 2003 ini kemudian mulai diatur secara tegas dalam Undang-Undang Nomor 31 Tahun

\footnotetext{
${ }^{48}$ Wawancara tanggal 29 Juni 2015.
} 
2014 tentang Perlindungan Saksi dan Korban. Adapun kesimpulan dari artikel ini adalah sebagai berikut:

Di Indonesia pemberian perlindungan baik fisik, hukum dan penanganan secara khusus bagi Justice Collaborator baru diterapkan untuk saksi pelaku untuk pengungkapan tindak pidana korupsi. Praktiknya pun sudah berlangsung sebelum lahirnya Undang-Undang Nomor 31 Tahun 2014. Walhasil KPK hanya memberikan perlindungan bagi saksi murni. Sedangkan untuk Justice Collaborator diserahkan sepenuhnya oleh Lembaga Perlindungan Saksi dan Korban.

Pemberian perlindungan fisik bagi Justice Collaborator tindak pidana korupsi berbeda antara satu dengan yang lainnya. Pihak KPK bekerjasama dengan Lembaga Perlindungan Saksi dan Korban memberlaku standar tingkat ancaman bagi JC yang akan dilindungi. Berdasarkan penelitian untuk JC dalam kasus suap Wisma Atlet diberikan perlindungan secara full karena saksi sering diancam untuk dibunuh, berbeda untuk JC dalam kasus cek pelawat/ pemilihan Deputi Gubernur Senior Bank Indonesia yang tidak meminta untuk dilindungi.

Untuk pemberian perlindungan hukum bagi Justice Collaborator tindak pidana juga sangatlah penting, karena tidak jarang banyak kasus yang dilaporkan Whistleblowers atau Justice Collaborator justru mereka yang dilapor balik telah melakukan tindak pidana pencemaran nama baik. Khusus untuk tindak pidana korupsi berdasarkan penelitian baik KPK maupun LPSK belum pernah mendapatkan seorang Justice Collaborator yang mereka lindungi dilapor balik pencemaran nama baik.

Selain pemberian perlindungan baik fisik dan perlindungan hukum, dikenal juga penanganan secara khusus oleh penegak hukum terhadap Justice Collaborator perkara korupsi. Penanganan secara khusus berupa pemisahan pemberkasan dalam praktiknya telah dilakukan oleh Komisi Pemberantasan 
Korupsi secara keseluruhan. Sedangkan untuk penanganan secara khusus berupa mengabulkan permohonan saksi pelaku/ Justice Collaborator untuk melaksanakan masa pidana di Lapas terdekat dengan kedaiam JC hanya diberikan kepada JC dalam kasus korupsi pemilihan Deputi Gubernur Senior Bank Indonesia.

Adapun saran atau rekomendasi Penulis adalah Pertama, menawarkan konsep perlindungan secara total/ menyeluruh kepada penegak hukum terhadap Justice Collaborator perkara korupsi yang dimulai dari seluruh tahapan sistem peradilan pidana. Kedua, mulai memberlakukan pemberian keterangan saksi Justice Collaborator via teleconference baik pada saat penyidikan maupun di sidang pengadilan. Ketiga, penegak hukum harus konsisten dalam memberikan perlindungan berupa menjaga rahasia identitas seorang Justice Collaborator agar tidak menjadi sasaran pengancaman.

\section{DAFTAR PUSTAKA}

Jupri, KPK \& Korupsi Kekuasaan, Penerbit Pusat Kajian Inovasi Pemerintahan dan Kerjasama Antar Daerah Program Studi Ilmu Pemerintahan FISIP Universitas Brawijaya, Malang, 2016

Mulyadi, Lilik, Perlindungan Hukum Whistleblower \& Justice Collaborator Dalam Upaya Penanggulangan Organized Crime, PT. Alumni, Bandung, 2015

Semendawai, Abdul Haris, Optimalisasi Perlakuan dan Perlindungan Bagi Whistleblower dan Justice Collaborator. Makalah disampaikan dalam kegiatan Kuliah Umum Fakultas Hukum Universitas Hasanuddin, Makassar 20 Oktober 2014

Seno Adji, Indriyanto, Korupsi dan Penegakan Hukum, Diadit Media, Jakarta, 2009

--------------------, Korupsi Kebijakan Aparatur Negara \& Hukum Pidana, Diadit Media, Jakarta, 2009

Wijaya, Firman, Whistle Blower dan Justice Collaborator Dalam Perspektif Hukum, Penaku, Jakarta, 2012 